\title{
ASSESSMENT ON KNOWLEDGE, ATTITUDE AND PRACTICE OF PATIENTS IN HOSPITAL TAPAH REGARDING DISPOSAL OF UNUSED AND EXPIRED MEDICINES
}

\author{
NUR FEAZIRA ABDUL KADIR, NUR SYAMIMI SUHAIMI, MALA BALAKRISHNAN, \\ WAN NURSYAHIRAH WAN ZAIDI AND SUI CHEE FAI ${ }^{*}$ \\ Department of Pharmacy, Hospital Tapah, Perak, Malaysia
}

Published online: 24 May 2021

To cite this article: NUR FEAZIRA ABDUL KADIR, NUR SYAMIMI SUHAIMI, MALA BALAKRISHNAN, WAN NURSYAHIRAH WAN ZAIDI \& SUI CHEE FAI (2021) Assessment on knowledge, attitude and practice of patients in Hospital Tapah regarding disposal of unused and expired medicines, Malaysian Journal of Pharmaceutical Sciences, 19(1): 1-18, https://doi.org/10.21315/mjps2021.19.1.1

To link to this article: https://doi.org/10.21315/mjps2021.19.1.1

\begin{abstract}
According to the World Health Organization (WHO), more than half of dispensed medications were inappropriately prescribed, which causes a build-up of unused medications and increasing medication disposal. The aim of this study is to assess the level of knowledge, attitude and current practice of patients in Hospital Tapah, Perak, Malaysia towards this issue. A cross-sectional study was conducted by using a selfadministered questionnaire adapted from Su Lan et al. (2018). Patients aged more than 17 years old who visited outpatient pharmacy and who admitted into medical ward; the caregivers of children who admitted into paediatric ward, Hospital Tapah were enrolled in this study, selected through convenience sampling. Logistic regression analysis was performed to determine significant association between independent and dependent parameters. The significance level was set at $p<0.1$. Total of 344 valid questionnaires were returned in which $34.9 \%(n=120)$ men and $65.1 \%(n=224)$ women participated. The majority of the participants has general knowledge of the correct way of disposing medicines. Although $57.3 \%$ of the participants have heard about 'Return Your Medicines Programme' (RMP) implemented by the Ministry of Health Malaysia, only $38.1 \%$ returned their unused or expired medication to the nearby hospital/clinic. Most of them were found to have a positive attitude regarding this issue, nevertheless only $24.7 \%$ practiced a proper medication disposal. The utilisation of RMP could be improved by increasing the awareness of safe medication disposal, as significant association has been found between the level of knowledge and attitude with current disposal practice of patients in Hospital Tapah.
\end{abstract}

Keywords: Disposal, Unused and expired medicines, Knowledge, Attitude, Practice

*Corresponding author: suicheefai@moh.gov.my

(C) Penerbit Universiti Sains Malaysia, 2021. This work is licensed under the terms of the Creative Commons Attribution (CC BY) (http://creativecommons.org/licenses/by/4.0/). 


\section{INTRODUCTION}

According to the World Health Organization (WHO), rational use of medicine is defined as "patients receive medications appropriate to their clinical needs, in doses that meet their own individual requirements, for an adequate period of time, and at the lowest cost to them and their community" (WHO 2002). The increment of disease incidence and prevalence is the main factor that leads to the different medications being utilised for treatment and disease prevention. It was reported that more than half of dispensed medications were inappropriately prescribed, which causes unnecessary storage of medicine and creating environmental threat (Bashaar et al. 2017).

The improper storage of unused and expired medicine can cause unintentional poisoning for other people, especially vulnerable group such as young children. This may also promote or lead to drug diversion such as medication abuse or misuse. However, the main concern with this issue is the incorrect way of medication disposal which could contaminate the environment and pose risk to water, air, agricultural products and even harm animals or livestock (Bashaar et al. 2017).

Patient's incompliance towards their own medications also contributes to drug wastage. For example, excessive analgesics that are prescribed and supplied to patients with chronic pain due to their osteoarthritic condition may result in medication wastage as patient only consume the drug when needed, with maximum dose per day according to the specific medication. Some of the medications were even left untouched until they expired (Su Lan et al. 2018).

In 2010, Pharmaceutical Service Division, Ministry of Health Malaysia had implemented a programme called 'Return Your Medicines Programme (RMP)' which emphasised on the safe disposal of patients' unused and excess medicines. The objectives of this programme are to preserve the environment from hazardous pharmaceutical compounds resulting from improper disposal of medications, and prevent accidental ingestion caused by improper storage and misuse or abuse of extra medications (Ministry of Health Malaysia 2013; Su Lan et al. 2018). However, there is lack of statistical evidences regarding the progress of this programme, and the knowledge regarding the current practice of unused and expired medication disposal as well as the guideline regarding the issue are still inadequate for the public in Malaysia as public awareness and education on environmental hazard caused by improper disposal of medications are largely unknown (Su Lan et al. 2018).

Lack of studies had been conducted regarding disposal of unused and expired medicines among patients in hospital setting, especially district hospital. Hospital Tapah is a district government hospital located in Tapah, Perak. It is a secondary hospital, i.e. a hospital without specialists and it only handles uncomplicated cases. Hospital Tapah is one of the oldest hospital in Perak since 1888 (Hospital Tapah 2016). The respective hospital was chosen for this study as there is lack of studies done regarding the knowledge, attitude and practice (KAP) of medication disposal in district or secondary hospitals. On 2018, a study was conducted in 33 outpatient pharmacies in Sabah healthcare facilities including tertiary hospital has been done (Su Lan et al. 2018). It is important to include the population in a small district to participate in a study and also to increase their awareness on the issue. Therefore, the aim of the study was to assess and report the level of knowledge, the attitude and current practice of patients specifically in Hospital Tapah regarding the disposal of unused and expired medications.

Malay J Pharm Sci, Vol. 19, No. 1 (2021): 1-18 


\section{METHODS}

\section{Study Design and Recruitment}

A cross-sectional study was done to assess the level of KAP of patients in Hospital Tapah regarding disposal of unused and expired medicines. Data were collected within five months starting in May 2019, by distributing validated questionnaire to the patients who visited outpatient pharmacy, patients who were admitted into medical ward and the caregivers of children who were admitted into paediatric ward, Hospital Tapah. Distribution of the questionnaires to the subjects was conducted via 'self-administration'. The respondents were selected through convenience sampling. Distribution of questionnaires was conducted by four pharmacists who were involved in this study and all filled questionnaires were collected by respective researchers on the same day.

\section{Survey Instrument}

Questionnaire prepared was adapted from the Utilisation of Medication Return Programme, Knowledge and Disposal Practice of Unused Medication, a validated questionnaire in Malaysia (Su Lan et al. 2018). It comprised of four sections. Section A was made up of sociodemographic data of the respondents. Section B (knowledge) consisted of nine questions. The answers provided were in the form of 'Correct', 'Incorrect' and 'Do not know'. For every positive answer, which represent good knowledge was scored 1 point, the negative answers and 'Do not know' were scored 0 point. The total score of 7 to 9 was defined as good knowledge, while 0 to 6 was defined as poor knowledge.

Section $\mathrm{C}$ (attitude) consisted of nine questions. Six questions from this section were situation-based question which was assessed by using 5-point Likert scale of 'strongly disagree' to 'strongly agree'. For every positive answer which represents good attitude was scored 4 to 5 points while the negative attitude was scored 1 to 3 . For the other questions, positive answer was scored 1 while negative answer was scored 0 . The total score of 25 to 31 was defined as positive attitude, while 6 to 24 was defined as negative attitude.

Section D (practice) consisted of seven situation-based questions, each having 'Yes' and 'No' options. For every positive practice, 1 point was given, whereas for every negative/poor practice 0 points was given. Total score of 7 was concluded as having good practice. For subjects who scored 0 to 6 points were concluded as having poor practice on disposal of unused and expired drugs.

The questionnaire was validated by both Malay and English language teachers. Pilot test was conducted by 10 pharmacists working in Hospital Tapah in order to determine subjects' understanding towards our questionnaire as well as the feasibility of subject recruitment and research tool used. Questionnaire content was edited according to their feedback. The reliability of the questionnaire was measured by using Cronbach's alpha. The value for Cronbach's alpha obtained from pilot study was 0.78 .

\section{Inclusion and Exclusion Criteria}

\section{Inclusion criteria}

Patients aged more than 17 years old who visited outpatient pharmacy and who admitted into medical ward (male and female) and the caregivers of children who admitted into paediatric ward, Hospital Tapah. 


\section{Exclusion Criteria}

Incomplete questionnaires/data, respondents who do not understand Bahasa Malaysia or English, prisoners and foreigners, patients/caregivers who declined the consent to participate in this study and psychiatric patients.

\section{Sample Size}

Sample size for this study was calculated based on Yamane's formula (Glenn 2003). The total population size $(2,470$ patients) was taken from the previous statistical outpatient department and in-patient department record which represents data for approximately, one month. By setting the confidence level at $95 \%$ and $5 \%$ margin of error, the calculated sample size was 344 .

\section{Statistical Analysis}

The collected data were analysed using Statistical Package for the Social Sciences (SPSS) version 16.0 software. Categorical data were presented in the form of frequency and percentage (refer Tables 1 to 8). Logistic regression (bivariate and multivariate regression analysis) was performed to determine the significant association between dependent and independent parameters. A crude odd ratio (OR) in Tables 3,5 and 7 is an OR of one independent variable for predicting the dependent variable while the adjusted OR provides the potential variable of interest which is adjusted for the other independent variables included in the study. The significance level was set at $p<0.1$.

\section{Ethics Approval}

This study was conducted in accordance to the ethical principles outlined in the Declaration of Helsinki and Malaysian Good Clinical Practice Guideline. The National Medical Research Registration (NMRR) code for the study is NMRR-19-749-46746.

\section{RESULTS}

\section{Sociodemographic Characteristics}

The sociodemographic characteristics of patients were summarised in Table 1. Of the 344 patients, 120 (34.9\%) were men and 224 (65.1\%) were women. Maximum (143; 41.6\%) patients were young adult aged 18 to 35 years old. It was found that $221(64.2 \%)$ patients were Malay, 66 (19.2\%) were Indian, $42(12.2 \%)$ were Orang Asli and $15(4.4 \%)$ were Chinese. More than half of the patients $(199 ; 57.8 \%)$ had up to secondary education, while $99(28.8 \%)$ had up to tertiary education and the rest were patients with no formal education or with primary education. 
Table 1: Sociodemographic characteristics of the participants.

\begin{tabular}{|c|c|}
\hline Characteristics & $\begin{array}{c}\text { Responses }(\%) \\
(n=344)\end{array}$ \\
\hline \multicolumn{2}{|l|}{ Gender } \\
\hline Men & $120(34.9)$ \\
\hline Women & $224(65.1)$ \\
\hline \multicolumn{2}{|l|}{ Age (years old) } \\
\hline $18-35$ & $143(41.6)$ \\
\hline $36-55$ & $134(39.0)$ \\
\hline $56-89$ & $67(19.5)$ \\
\hline \multicolumn{2}{|l|}{ Races } \\
\hline Malay & $221(64.2)$ \\
\hline Chinese & $15(4.4)$ \\
\hline Indian & $66(19.2)$ \\
\hline Orang Asli & $42(12.2)$ \\
\hline \multicolumn{2}{|l|}{ Educational level } \\
\hline No formal education & $12(3.5)$ \\
\hline Primary & $34(9.9)$ \\
\hline Secondary & $199(57.8)$ \\
\hline Tertiary & $99(28.8)$ \\
\hline \multicolumn{2}{|l|}{ Occupation } \\
\hline Government & $86(25.0)$ \\
\hline Private & $58(16.9)$ \\
\hline Self-employed & $55(16.0)$ \\
\hline Unemployed/Retired & $53(15.4)$ \\
\hline Student & $14(4.1)$ \\
\hline Housewife & $78(22.7)$ \\
\hline \multicolumn{2}{|l|}{ Distance (km) } \\
\hline $0-10$ & $229(66.6)$ \\
\hline $11-20$ & $77(22.4)$ \\
\hline $21-30$ & $25(7.3)$ \\
\hline$>30$ & $13(3.8)$ \\
\hline \multicolumn{2}{|l|}{ Marital status } \\
\hline Single & $62(18.0)$ \\
\hline Married & $263(76.5)$ \\
\hline Divorced/Widowed & $19(5.5)$ \\
\hline
\end{tabular}




\section{Knowledge of Patients Regarding Disposal of Unused and Expired Medicines}

Table 2 shows the level of knowledge on disposal of unused and expired medicines of the patients. Of the 344 patients, $272(79.1 \%)$ were aware that inappropriate disposal of medicines will contaminate the environment, and most of the patients $(83.1 \%, n=286)$ knew that the unused or expired medicines can be returned back to nearby hospital or clinic for a proper disposal. More than $70 \%$ of the patients also knew that it was wrong to dispose medications by flushing them down a toilet, pouring them down a sink, giving them to friends/relatives, burning them openly, and disposing them to the environment. However, almost half of the patients $(42.7 \%, n=147)$ thought that medicines which have not been used or have expired may be disposed by throwing it into a trash can. The study discovered that $57.3 \%(n=197)$ of the patients have actually heard about RMP implemented by the Ministry of Health Malaysia.

Table 2: Level of knowledge of the participants on disposal of unused and expired medicines.

\begin{tabular}{lcc}
\hline \multirow{2}{*}{ Variables and categories } & \multicolumn{2}{c}{$\begin{array}{c}\text { Responses (\%) } \\
(\boldsymbol{n}=\mathbf{3 4 4})\end{array}$} \\
\cline { 2 - 3 } & Correct & Incorrect \\
\hline $\begin{array}{l}\text { Inappropriate disposal of medicines will contaminate } \\
\text { the environment }\end{array}$ & $272(79.1)$ & $72(20.9)$ \\
$\begin{array}{l}\text { Unused or expired medicines may be disposed of in } \\
\text { such manners: }\end{array}$ & & \\
$\quad$ Flush down a toilet bowl & $88(25.6)$ & $256(74.4)$ \\
Pour down a sink & $92(26.7)$ & $252(73.3)$ \\
$\quad$ Give to friends or relatives & $50(14.5)$ & $294(85.5)$ \\
$\quad$ Burn & $85(24.7)$ & $259(75.3)$ \\
Dispose to the environment (e.g. river, soil) & $64(18.6)$ & $280(81.4)$ \\
Throw into a trash & $147(42.7)$ & $197(57.3)$ \\
Return back to nearby hospital or clinic & $286(83.1)$ & $58(16.9)$ \\
\hline
\end{tabular}

Table 3 illustrates the bivariate and multivariate analysis of factors associated with knowledge outcome. Five factors namely age, race, educational level, occupation and marital status were significantly associated with knowledge in bivariate analysis; however, following multivariate logistic regression; only Bumiputera $(p=0.023)$ was significant. Based on multivariate logistic regression, good knowledge has 4.2 times good practice of medication disposal than poor knowledge. 
Table 3: Factors associated with the good knowledge (using bivariate and multivariate regression analysis).

\begin{tabular}{|c|c|c|c|c|}
\hline Variable & $\begin{array}{l}\text { Crude OR } \\
(95 \% \mathrm{Cl})\end{array}$ & $p$-value & $\begin{array}{c}\text { Adjusted OR } \\
(95 \% \mathrm{Cl})\end{array}$ & $p$-value \\
\hline \multicolumn{5}{|l|}{ Gender } \\
\hline Male & Reference & & & \\
\hline Female & $1.20(0.75-1.94)$ & 0.449 & & \\
\hline Age & $1.02(1.01-1.04)$ & 0.006 & $1.01(0.99-1.03)$ & 0.285 \\
\hline \multicolumn{5}{|l|}{ Races } \\
\hline Malay & Reference & & Reference & \\
\hline Chinese & $1.39(0.38-5.10)$ & 0.620 & $1.42(0.36-5.68)$ & 0.618 \\
\hline Indian & $0.75(0.41-1.36)$ & 0.335 & $0.76(0.40-1.44)$ & 0.396 \\
\hline Bumiputera & $0.32(0.16-0.62)$ & 0.001 & $0.41(0.19-0.88)$ & 0.023 \\
\hline \multicolumn{5}{|l|}{ Educational Level } \\
\hline No formal & Reference & & Reference & \\
\hline Primary & $4.67(1.11-19.59)$ & 0.035 & $3.46(0.75-15.97)$ & 0.112 \\
\hline Secondary & $2.11(0.66-6.78)$ & 0.211 & $1.83(0.50-6.65)$ & 0.361 \\
\hline Tertiary & $2.67(0.79-8.99)$ & 0.114 & $2.18(0.55-8.63)$ & 0.268 \\
\hline \multicolumn{5}{|l|}{ Occupation } \\
\hline Government & Reference & & Reference & \\
\hline Private & $1.85(0.83-4.13)$ & 0.132 & $1.98(0.86-4.59)$ & 0.110 \\
\hline Self employed & $0.78(0.38-1.59)$ & 0.496 & $0.83(0.38-1.82)$ & 0.634 \\
\hline Unemployed/Retired & $1.44(0.65-3.19)$ & 0.363 & $1.23(0.51-2.95)$ & 0.640 \\
\hline Student & $0.33(0.10-1.03)$ & 0.056 & $0.46(0.12-1.76)$ & 0.256 \\
\hline Housewife & $0.87(0.45-1.67)$ & 0.670 & $1.04(0.50-2.17)$ & 0.919 \\
\hline \multicolumn{5}{|l|}{ Distance (km) } \\
\hline $0-10$ & Reference & & & \\
\hline $11-20$ & $1.25(0.70-2.21)$ & 0.449 & & \\
\hline $21-30$ & $1.87(0.68-5.18)$ & 0.228 & & \\
\hline$>30$ & $1.05(0.31-3.53)$ & 0.933 & & \\
\hline \multicolumn{5}{|l|}{ Marital status } \\
\hline Single & Reference & & & \\
\hline Married & $1.45(0.81-2.59)$ & 0.208 & & \\
\hline Divorced/Widowed & $2.21(0.66-7.47)$ & 0.201 & & \\
\hline
\end{tabular}




\section{Attitude of Patients Regarding Disposal of Unused and Expired Medicines}

Table 4 shows the responses of patients to the statements provided intended to measure the attitude of patients towards disposal of unused or expired medicines and its environmental impact. Majority of the patients strongly agreed that unused medicines need to be returned back to hospital/clinic $(n=202,58.7 \%)$ and strongly disagreed that medicines was thrown into a trash/sink/toilet hole because it was easier $(n=157,45.6 \%)$. It was found that 189 $(54.9 \%)$ of patients strongly agreed that returning back the unused and expired medicines to nearby hospital/clinic is the best way to dispose medications because $175(50.9 \%)$ of them strongly agreed that disposing medications recklessly will affect the environment. Of 344 patients, $192(55.8 \%)$ of them strongly agreed that the public has to know the correct way to dispose unused or expired medicines and 179 (52.0\%) of them strongly agreed that the knowledge regarding medication disposal is important as it is actually a pretty serious issue. A slim majority of the patients $(n=131,38.1 \%)$ believed that information on proper disposal of medicine provided through advertisements via television, newspaper and social media is the best way to promote the awareness.

Table 4: Attitude of the participants on disposal of unused and expired medicines.

\begin{tabular}{|c|c|c|c|c|c|c|}
\hline \multicolumn{2}{|c|}{$\begin{array}{l}\text { Questions (Please tick (/) whichever that } \\
\text { is necessary) }\end{array}$} & \multirow{2}{*}{$\begin{array}{c}\begin{array}{c}\text { Strongly } \\
\text { disagree } \\
\boldsymbol{n}(\%)\end{array} \\
16(4.7)\end{array}$} & \multirow{2}{*}{$\begin{array}{c}\text { Disagree } \\
\qquad \boldsymbol{n}(\%)\end{array}$} & \multirow{2}{*}{$\begin{array}{c}\begin{array}{c}\text { Neutral } \\
n(\%)\end{array} \\
57(16.6)\end{array}$} & \multirow{2}{*}{$\begin{array}{c}\begin{array}{c}\text { Agree } \\
\boldsymbol{n}(\%)\end{array} \\
53(15.4)\end{array}$} & \multirow{2}{*}{$\begin{array}{c}\begin{array}{c}\text { Strongly } \\
\text { agree } \\
n(\%)\end{array} \\
202(58.7)\end{array}$} \\
\hline 1 & $\begin{array}{l}\text { Medicines that have not been used need } \\
\text { to be returned back to hospital/pharmacy/ } \\
\text { clinic. }\end{array}$ & & & & & \\
\hline 2 & $\begin{array}{l}\text { I throw it in a trash/sink/toilet hole } \\
\text { because it was easier. }\end{array}$ & $157(45.6)$ & $32(9.3)$ & $59(17.2)$ & $46(13.4)$ & $50(14.5)$ \\
\hline 3 & $\begin{array}{l}\text { The best way to dispose expired } \\
\text { medicines is by returning back to } \\
\text { nearby hospital/pharmacy/clinic. }\end{array}$ & $13(3.8)$ & $12(3.5)$ & 65 (18.9) & 65 (18.9) & $189(54.9)$ \\
\hline 4 & $\begin{array}{l}\text { I think disposing medication in any } \\
\text { way will never affect the environment. }\end{array}$ & $175(50.9)$ & $56(16.3)$ & $54(15.7)$ & 27 (7.9) & $32(9.3)$ \\
\hline 5 & $\begin{array}{l}\text { I think the public has to know the correct } \\
\text { way of medication disposal because it } \\
\text { can reduce environmental pollution. }\end{array}$ & $17(4.9)$ & $15(4.4)$ & $51(14.8)$ & 69 (20.1) & $192(55.8)$ \\
\hline 6 & $\begin{array}{l}\text { Knowledge regarding medication } \\
\text { disposal is not important because } \\
\text { it is not a serious issue for me. }\end{array}$ & $179(52.0)$ & $32(9.3)$ & 64 (18.6) & $41(11.9)$ & $28(8.1)$ \\
\hline
\end{tabular}

Table 5 illustrates the bivariate and multivariate analysis of factors associated with attitude outcome. Five factors namely gender, race, educational level, occupation and distance from home to nearby hospital/clinic were significantly associated with attitude in bivariate analysis; however, following multivariate logistic regression; only gender $(p=0.012)$, race $(p=0.014)$ and educational level $(p=0.002)$ were found to be significantly associated with attitude. Based on multivariate logistic regression, positive attitude has 7.2 times good practice of medication disposal than negative attitude. 
Table 5: Factors associated with the positive attitude (using bivariate and multivariate regression analysis).

\begin{tabular}{|c|c|c|c|c|}
\hline Variable & $\begin{array}{l}\text { Crude OR } \\
(95 \% \mathrm{Cl})\end{array}$ & $p$-value & $\begin{array}{c}\text { Adjusted OR } \\
(95 \% \mathrm{Cl})\end{array}$ & $p$-value \\
\hline \multicolumn{5}{|l|}{ Gender } \\
\hline Male & Reference & & Reference & \\
\hline Female & $1.88(1.13-3.13)$ & 0.016 & $2.27(1.20-4.31)$ & 0.012 \\
\hline Age & $1(0.99-1.02)$ & 0.539 & & \\
\hline \multicolumn{5}{|l|}{ Races } \\
\hline Malay & Reference & & Reference & \\
\hline Chinese & $0.70(0.21-2.31)$ & 0.562 & $1.09(0.28-4.23)$ & 0.896 \\
\hline Indian & $1.04(0.52-2.08)$ & 0.906 & $1.44(0.68-3.06)$ & 0.343 \\
\hline Bumiputera & $0.34(0.17-0.68)$ & 0.002 & $0.37(0.17-0.82)$ & 0.014 \\
\hline \multicolumn{5}{|l|}{ Educational level } \\
\hline No formal & Reference & & Reference & \\
\hline Primary & $11.60(2.51-53.58)$ & 0.002 & $13.41(2.63-68.38)$ & 0.002 \\
\hline Secondary & $5.80(1.68-20.09)$ & 0.006 & $4.78(1.22-18.71)$ & 0.025 \\
\hline Tertiary & $10.38(2.79-38.61)$ & 0.000 & $5.84(1.34-25.44)$ & 0.019 \\
\hline \multicolumn{5}{|l|}{ Occupation } \\
\hline Government & Reference & & Reference & \\
\hline Private & $0.67(0.29-1.56)$ & 0.357 & $0.68(0.28-1.68)$ & 0.406 \\
\hline Self employed & $0.49(0.22-1.10)$ & 0.083 & $0.57(0.23-1.40)$ & 0.220 \\
\hline Unemployed/Retired & $0.40(0.18-0.90)$ & 0.028 & $0.41(0.17-1.01)$ & 0.052 \\
\hline Student & $2.53(0.31-20.91)$ & 0.390 & $3.02(0.33-27.68)$ & 0.328 \\
\hline Housewife & $0.60(0.28-1.31)$ & 0.200 & $0.57(0.27-1.42)$ & 0.226 \\
\hline \multicolumn{5}{|l|}{ Distance (km) } \\
\hline $0-10$ & Reference & & & \\
\hline $11-20$ & $0.68(0.38-1.22)$ & 0.199 & & \\
\hline $21-30$ & $1.09(0.39-3.05)$ & 0.871 & & \\
\hline$>30$ & $0.61(0.18-2.07)$ & 0.431 & & \\
\hline \multicolumn{5}{|l|}{ Marital status } \\
\hline Single & Reference & & & \\
\hline Married & $0.95(0.49-1.83)$ & 0.868 & & \\
\hline Divorced/Widowed & $1.09(0.31-3.83)$ & 0.889 & & \\
\hline
\end{tabular}




\section{Practice of Patients Regarding Disposal of Unused and Expired Medicines}

Table 6 shows current practice of the patients on the disposal of unused or expired medications. Of 344 patients, only $131(38.1 \%)$ returned their medicines back to hospital/ clinic. It was also discovered that $150(43.6 \%)$ patients threw their medicines into a trash, $51(14.8 \%)$ poured the medicines down a sink, $37(10.8 \%)$ burnt their medicines, $33(9.6 \%)$ flushed their medicines down a toilet bowl, $22(6.4 \%)$ disposed their medicines to environment and $18(5.2 \%)$ patients gave their medicines to their friends or relatives.

Table 6: Current practice of the participants on disposal of unused and expired medicines.

\begin{tabular}{lrrrrr}
\hline \multirow{2}{*}{ Practice } & \multicolumn{5}{c}{$\begin{array}{c}\text { Responses (\%) } \\
(\boldsymbol{n}=\mathbf{3 4 4 )}\end{array}$} \\
\cline { 2 - 6 } & \multicolumn{3}{c}{ Yes } & \multicolumn{3}{c}{ No } \\
\hline Return back the medicine to hospital/clinic & 131 & $(38.1)$ & 213 & $(61.9)$ \\
Throw the medicine into a trash & 150 & $(43.6)$ & 194 & $(56.4)$ \\
Flush the medicine down a toilet bowl & 33 & $(9.6)$ & 311 & $(90.4)$ \\
Pour the medicine down a sink & 51 & $(14.8)$ & 293 & $(85.2)$ \\
Give the medicine to friends or relatives & 18 & $(5.2)$ & 326 & $(94.8)$ \\
Burn the medicine & 37 & $(10.8)$ & 307 & $(89.2)$ \\
Dispose the medicine to environment (e.g. river, soil) & 22 & $(6.4)$ & 322 & $(93.6)$ \\
\hline
\end{tabular}

Table 7 illustrates the bivariate and multivariate analysis of factors associated with practice outcome. Five factors namely gender, age, race, occupation and marital status were significantly associated with practice in bivariate analysis; however, following multivariate logistic regression; only age $(p=0.031)$ and occupation $(p=0.012)$ were found to be significantly associated with practice. The level of knowledge and attitude were also significantly associated with practice in multivariate logistic regression; both $p$-value were 0.001 .

Table 8 illustrates the summary for level of knowledge, attitude and current practice of patients in Hospital Tapah. Of 344 patients, $70.1 \%(n=241)$ had general knowledge on the correct way of disposing unused and expired medicines, $76.7 \%(n=264)$ were found to have positive attitude regarding the disposal of unused and expired medicines, nevertheless only $24.7 \%(n=85)$ of the patients practiced a proper medication disposal. 
Table 7: Factors associated with the good practice (using bivariate and multivariate regression analysis).

\begin{tabular}{|c|c|c|c|c|}
\hline Variable & $\begin{array}{l}\text { Crude OR } \\
(95 \% \mathrm{Cl})\end{array}$ & $p$-value & $\begin{array}{c}\text { Adjusted OR } \\
(95 \% \mathrm{Cl})\end{array}$ & $p$-value \\
\hline \multicolumn{5}{|l|}{ Gender } \\
\hline Male & Reference & & & \\
\hline Female & $1.50(0.88-2.56)$ & 0.140 & & \\
\hline Age & $1.02(1.01-1.04)$ & 0.004 & $1.02(1.00-1.05)$ & 0.031 \\
\hline \multicolumn{5}{|l|}{ Races } \\
\hline Malay & Reference & & Reference & \\
\hline Chinese & $1.00(0.31-3.26)$ & 0.998 & $1.40(0.39-5.01)$ & 0.603 \\
\hline Indian & $0.88(0.46-1.66)$ & 0.691 & $1.05(0.53-2.09)$ & 0.885 \\
\hline Bumiputera & $0.46(0.18-1.14)$ & 0.094 & $0.55(0.21-1.47)$ & 0.236 \\
\hline \multicolumn{5}{|l|}{ Educational level } \\
\hline No formal & Reference & & & \\
\hline Primary & 0.00 & 0.999 & & \\
\hline Secondary & 0.00 & 0.999 & & \\
\hline Tertiary & 0.00 & 0.999 & & \\
\hline \multicolumn{5}{|l|}{ Occupation } \\
\hline Government & Reference & & Reference & \\
\hline Private & $0.66(0.31-1.40)$ & 0.277 & $0.68(0.31-1.48)$ & 0.330 \\
\hline Self employed & $0.30(0.12-0.74)$ & 0.009 & $0.29(0.11-0.76)$ & 0.012 \\
\hline Unemployed/Retired & $0.62(0.28-1.37)$ & 0.236 & $0.46(0.19-1.13)$ & 0.092 \\
\hline Student & 0.00 & 0.998 & 0.00 & 0.999 \\
\hline Housewife & $0.92(0.48-1.78)$ & 0.806 & $0.78(0.38-1.60)$ & 0.504 \\
\hline \multicolumn{5}{|l|}{ Distance (km) } \\
\hline 0-10 & Reference & & & \\
\hline $11-20$ & $0.84(0.46-1.54)$ & 0.572 & & \\
\hline $21-30$ & $0.38(0.11-1.30)$ & 0.122 & & \\
\hline$>30$ & $0.83(0.22-3.10)$ & 0.777 & & \\
\hline \multicolumn{5}{|l|}{ Marital status } \\
\hline Single & Reference & & Reference & \\
\hline Married & $2.96(1.29-6.81)$ & 0.011 & $1.58(0.64-3.92)$ & 0.324 \\
\hline Divorced/Widowed & $3.63(1.04-12.62)$ & 0.043 & $2.00(0.51-7.83)$ & 0.318 \\
\hline \multicolumn{5}{|l|}{ Knowledge } \\
\hline Poor & Reference & & Reference & \\
\hline Good & $6.56(2.91-14.80)$ & 0.000 & $4.21(1.82-9.75)$ & 0.001 \\
\hline \multicolumn{5}{|l|}{ Attitude } \\
\hline Negative & Reference & & Reference & \\
\hline Positive & $11.56(3.54-37.73)$ & 0.000 & $7.22(2.16-24.16)$ & 0.001 \\
\hline
\end{tabular}


Table 8: The summary for level of knowledge, the attitude and current practice of the participants in Hospital Tapah.

\begin{tabular}{lcr}
\hline Characteristics & \multicolumn{2}{c}{$\begin{array}{c}\text { Frequency (\%) } \\
(\boldsymbol{n}=344)\end{array}$} \\
\hline Knowledge scoring, median (IQR) & 241 & $(70.1)$ \\
$\quad$ Good & 103 & $(29.9)$ \\
$\quad$ Poor & & \\
Attitude scoring, median (IQR) & 264 & $(76.7)$ \\
$\quad$ Positive & 80 & $(23.3)$ \\
$\quad$ Negative & & \\
Practice scoring, median (IQR) & 85 & \\
$\quad$ Good & $24.7)$ \\
Poor & 259 & $(75.3)$ \\
\hline
\end{tabular}

\section{DISCUSSION}

Improper medication disposal has imposed a significant threat towards the environment especially to the aquatic life (Jobling et al. 2006). Lots of initiative has been initiated around the world to help overcoming the issue. In Malaysia, RMP has been implemented in 2010 by the Ministry of Health Malaysia to promote the public to return their unused or expired medications to be disposed correctly and safely. This study was done to assess the KAP of patients in Hospital Tapah regarding the disposal of unused or expired medicines as to see if the programme actually worked.

This study found that majority of the participants were aware that the practice of disposing medications by flushing them down a toilet, pouring them down a sink, giving them to friends/relatives, burning them openly, and disposing them to environment are incorrect and that it should be returned back to hospitals/clinics instead. A high percentage $(79.1 \%)$ of patients were also aware that inappropriate medication disposal will contaminate the environment, similar with the findings of others (Ariffin and Zakili 2019). However, almost half of the participants $(42.7 \%)$ still think that disposing medications by throwing them into their household garbage was the most suitable practice. A study conducted in Selangor also reported that only $66 \%$ of the respondents were aware that it was wrong to dump pharmaceutical waste into rubbish bins (Ariffin and Zakili 2019).

Although more than half of the participants (57.3\%) knew about the RMP implemented by Ministry of Health Malaysia in 2010, only a low percentage $(38.1 \%)$ of patients returned their unused or expired medications to hospitals/clinics. Su Lan et al. (2018) found that $54 \%$ of patients were aware about the RMP provided by Ministry of Health Malaysia, but only $26 \%$ of them made use of the service provided. Likewise, a study done by Ariffin and Zakili (2019) found that $66 \%$ of the participants were aware about the RMP provided by Ministry of Health Malaysia but only one-fourth of them returned the unused or expired medications to the nearby pharmacies or healthcare facilities. This shows that RMP service provided by Ministry of Health Malaysia is not very well known to the public, hence the low utilisation rate of the service. The variation in the promotion of RMP in different health facilities were noticeable and it could be one of the factors that lead to the low

Malay J Pharm Sci, Vol. 19, No. 1 (2021): 1-18 
utilisation. It is suggested for the government to have a better awareness-building strategy and standardise it across all health facilities in Malaysia (Su Lan et al. 2018).

Numerous studies done globally regarding this issue also found that a large number of people were not aware about the proper medication disposal method. For example, many people in Kenya claimed that there were lack awareness campaigns done by their government as well as lack of information provided by their healthcare professionals regarding the issue (Angi'enda and Bukachi 2016). Correspondingly, households in Lebanon were also not aware about the correct medication disposal practice as there were lack of information and guidelines regarding the management of unused or expired medications (Massoud et al. 2016).

The unused and expired drugs were mostly discarded in the way that potentially harm the environment. For instance, medication disposal through household garbage may increase the risk of incidental exposure to pets or children, causing potential harm or even death (Glassmeyer and Hinchey 2009). Disposal of medication by means of flushing it down the toilet or rinsing it down the sink may significantly give rise to the contamination of the local water system which supplies water for the local population as most of the water treatment systems are designed for eliminating pathogens, particulate matter, nutrients, and odours, but not a tiny dissolved active ingredient (Shealy, O'Day and Eagerton 2014).

Medication that were disposed by flushing down the toilet may also travel to the sewage system and infiltrate streams, rivers, and lakes, causing the exposure of hazardous elements in the medications to the humans and marine life (Kinrys and Gold 2018). Steroid estrogens found in 39 rivers all over the United Kingdom (UK) has been shown to cause endocrine disorder in the wild fish populations by altering their sexual orientation, causing intersex in them (Jobling et al. 2006). The presence of antibiotics ciprofloxacin, cephalexin and norfloxacin in sewer systems and water streams result in antibiotic resistance of bacteria sampled in the affected area, which suggest potential risk of antibiotic resistance to those who consumed water from the affected rivers (Costanzo, Murby and Bates 2005).

A study in Sabah, Malaysia reported that the perception regarding implication to environment positively affected public decision to utilise the service implemented by Ministry of Health Malaysia as it was the safest disposal method for unused and expired medicines (Su Lan et al. 2018). In this study, most of the participants strongly agreed that unused and expired medicines need to be returned back to the hospital or clinic as it was the best way of disposing medications. Majority of people in Sweden and Korea returned their unused and expired medicines to hospital or clinic for correct disposal as they were concerned about its environmental implication (Bashaar et al. 2017).

Most of the participants were aware of the importance of proper medication disposal as they strongly agreed that it was a serious issue and they believed that improper disposal of medications would negatively affect the environment. Incorrect disposal of unused and expired medicines may lead to pollution because of the presence of active pharmaceutical ingredients (API) in medicines. The existence of pharmaceutical residues in the drains and drinking water in the United States of America (USA) had caught the attention of the public, regulators, as well as lawmakers there (Wu et al. 2009). A study that quantified the concentrations of 56 active ingredients in sewage samples from 50 huge wastewater treatment plants across the USA found that hydrochlorothiazide which is a diuretic was in each of the samples while antihypertensive drugs such as metoprolol and atenolol, and an anticonvulsant (carbamazepine) were found in over $90 \%$ of the samples (Kostich, Batt and Lazorchak 2014). This may result in potential hazard to humans especially those who are allergic or contraindicated to the drugs. 
From this study, it was found that many participants believed that information on proper disposal of medicine provided through advertisements via television, newspapers and social media is the best way to promote awareness to the public. A significant role can be played by doctors, pharmacists and nurses too in dissemination of information regarding the issue to increase public awareness. According to Glassmeyer and Hinchey (2009), the approaches used for collection scheme of unwanted medicines vary among countries, but in general, pharmacies play a central role. Some countries rely only on government funding as a financial support for drug collection, while others are supported through the pharmaceutical industry or the pharmacies themselves.

A campaign on proper medication disposal by government is crucial since many individuals did not aware of RMP implemented by Ministry of Health Malaysia back in 2010. Su Lan et al. (2018) mentioned a suggestion to incorporate creative educational programme into the 'Know Your Medicine' campaign. In the campaign, pharmacists should explain about the safety of drug utilisation and promote the RMP to the public in order to relay the information regarding safe medication disposal practice which should not be limited to just posters, leaflets or collection boxes.

Our study showed that most of the participants threw their medicines in the trash bin to dispose the unwanted medicines. Tong, Peake and Braund (2011) stated that majority of the respondents involved in their study threw away their expired medicines in the household trash, which is a negative way of disposing medications. Similar findings was reported by AIAzmi et al. (2017) which showed that $73 \%$ of the participants discarded leftover, expired, unwanted or unused medications by throwing them in the garbage or trash while $50 \%$ believed that giving leftover medications away to family, friends or charity centres was the best method of disposal. If the trash was incinerated, this might be the environmentally safe way of medication disposal, but if the waste was landfilled, it would possibly contaminating surrounding surface or ground waters (Kusturica, Tomas and Sabo 2016; Masoner et al. 2014).

Based on Tong, Peake and Braund (2011), liquid medications were more likely to be rinsed down the sink, as opposed to solid tablets and capsules, which were more likely to be deposited in the rubbish bin. It was found that $9.6 \%$ of the participants in this study practiced flushing the medicine down a toilet bowl. According to current Food and Drug Administration (FDA) guidelines, flushing down the toilet is the suitable disposal method for 23 extremely dangerous controlled substances as flushing down the drain limits potential exposure of children or pets and risks of accidental poisoning, which might have contributed to considerable quantities of flushed medication in American households (FDA 2015). According to Chasler (2011), previously, rinsing medicine in the sink was believed to be a proper method of handling unused or expired medications. It was also believed that flushing down the medications in toilet or draining them in sink was a good idea rather than discarding them in the trash, where animals or humans would be more likely to encounter them. However, it would contaminate the environment and pose significant risks to water, air, agricultural products, and food chain, even harm animals and livestock as these drains would eventually end up in the river or water system (Nakada et al. 2006; Patwary et al. 2009).

Based on our findings, $10.8 \%$ of participants practiced burning of unused and expired medications. Similarly, Kusturica et al. (2012) reported higher rate of medication burning in rural than in urban households in Serbia, while home backyard burning of expired and unused medication was commonly reported in Lithuania for respondents living in the countryside. Burning of waste in ordinary households should be avoided as it may produces various other contaminants releasing into the air causing a risk to human health and environment. 
This study also discovered that the level of knowledge and attitude were significantly associated with practice according to multivariate logistic regression (Table 7). There were few studies reported positive and strong association between knowledge and behaviour regarding the medication disposal practices. A study carried out in California, USA, discovered that respondents that were aware of this issue were less likely to use trash and toilet/sink for medication disposal and more likely to return medications to the pharmacy (Kotchen et al. 2009). A study in Sweden found that individual with awareness of the effects of pharmaceuticals deposited in the environment had the best practices among general public (Persson, Sabelström and Gunnarsson 2009).

This issue arises due to the unavailability of clear guidance regarding disposal of unused and expired medicines and there is a lack in knowledge on good medication disposal practice. Therefore, good practice guidelines or awareness should be implemented in all healthcare settings to improve disposal practices in our society. The regulatory bodies need to do a better job at minimising long disposal procedures and monitoring disposal practices for unused and expired medicines to improve people's understanding towards the important of proper medication disposal as well as promoting the return of unused or expired medications. This practice has been exercised since 1971 in Sweden which leads to their excellent current practice of medication disposal (Persson, Sabelström and Gunnarsson 2009).

Our health care providers, such as doctor, pharmacist and others, should check on the root of malpractice that leads to unused and expired medicines that might be caused by polypharmacy, inappropriate medicines taken, non-adherence of patients towards their medicines and other matters that lead to the main subject; improper medication disposal.

\section{CONCLUSION}

This study has established the evidence on the level of KAP of patients in Hospital Tapah regarding disposal of unused and expired medicines. The awareness and utilisation of RMP was not satisfying, yet could be improved by increasing the awareness of safe medication disposal as significant association has been found between the level of knowledge and attitude with current disposal practice.

\section{LIMITATIONS}

Our study was conducted in a single-centred study over a defined period. Therefore, it could not be used to generalise the level of KAP of the total population in Malaysia. Besides, this study was based on a self-administered questionnaire that could have contributed to recall bias when we interviewed a few of the illiterate participants. Several studies had reported that the study participants might provide wrong responses, depending on their ability to recall past event, as a result of recall error. However, the results may provide general ideas regarding the issue and can be a starting point for future welldesigned studies. 


\section{ACKNOWLEDGEMENTS}

We would like to thank the Director General of Health Malaysia for his permission to publish this article and the director of Hospital Tapah, Perak, Malaysia for the permission in conducting the research in the facility. We thank our colleague from Hospital Tapah for assistance and comments that were truly useful in improving the research. We also would like to show gratitude to Dr Lim Xin Jie from the Clinical Research Centre, Perak in helping us with the analysis of the data.

\section{REFERENCES}

ALAZMI, A., ALHAMDAN, H., ABUALEZZ, R., BAHADIG, F., BONOFAL, N. \& OSMAN, M. (2017) Patients' knowledge and attitude toward the disposal of medications, Journal of Pharmaceutics, 2017(1): 1-9. https://doi.org/10.1155/2017/8516741

ANGI'ENDA, S. A. \& BUKACHI, S. A. (2016) Household knowledge and perceptions on disposal practices of unused medicines in Kenya, Journal of Anthropology and Archaeology, 4(2): 1-20. https://doi.org/10.15640/jaa.v4n2a1

ARIFFIN, M. \& ZAKILI, T. S. T. (2019) Household pharmaceutical waste disposal in Selangor, Malaysia - Policy, public perception, and current practices, Environmental Management, 64(4): 509-519. https://doi.org/10.1007/s00267-019-01199-y

BASHAAR, M., THAWANI, V., HASSALI, M. A. \& SALEEM, F. (2017) Disposal practices of unused and expired pharmaceuticals among general public in Kabul, BMC Public Health, 2017(45): 1-8. https://doi.org/10.1186/s12889-016-3975-z

CHASLER, J. (2011) Tips for disposal of unused and expired medications, https://www. accp1.org/documents/TipsforDisposalofUnusedorExpiredMedications.pdf (1 January 2020).

COSTANZO, S., MURBY, J. \& BATES, J. (2005) Ecosystem response to antibiotics entering the aquatic environment, Marine Pollution Bulletin, 51(1-4): 218-223. https://doi.org/10.1016/j.marpolbul.2004.10.038

FOOD AND DRUG ADMINISTRATION (FDA) (2015) Disposal of unused medicines: What you should know, https://www.fda.gov/drugs/safe-disposal-medicines/disposal-unusedmedicines-what-you-should-know (1 January 2020).

GLASSMEYER, S. \& HINCHEY, E. (2009) Disposal practices for unwanted residential medications in the United States, Environment International, 35(3): 566-572. https://doi. org/10.1016/j.envint.2008.10.007

GLENN, D. (2003) Determining sample size, https://www.tarleton.edu/academicassessment/ documents/samplesize.pdf (1 January 2020).

HOSPITAL TAPAH (2016) Background of Hospital Tapah, http://htapah.moh.gov.my/v1/ index.php/en/kenali-kami/latar-belakang (1 January 2020).

Malay J Pharm Sci, Vol. 19, No. 1 (2021): 1-18 
JOBLING, S., WILLIAMS, R., JOHNSON, A. \& TAYLOR, A. (2006) Predicted exposures to steroid estrogens in U.K. rivers correlate with widespread sexual disruption in wild fish populations, Environmental Health Perspectives, 114(1): 32-39. https://doi.org/10.1289/ ehp.8050

KINRYS, G. \& GOLD, A. (2018) Medication disposal practices: Increasing patients and clinician education on safe methods, Journal of International Medical Research, 46(3): 927-939. https://doi.org/10.1177/0300060517738681

$\mathrm{KOSTICH}$, M., BATT, A. \& LAZORCHAK, J. (2014) Concentrations of prioritized pharmaceuticals in effluents from 50 large wastewater treatment plants in the US and implications for risk estimation, Environmental Pollution, 184: 354-359. https://doi.org/10 .1016/j.envpol.2013.09.013

KOTCHEN, M., KALLAOS, J., WHEELER, K., WONG, C. \& ZAHLLER, M. (2009) Pharmaceuticals in wastewater: Behaviour, preferences, and willingness to pay for a disposal program, Journal of Environmental Management, 90(3): 1476-1482. https://doi .org/10.1016/j.jenvman.2008.10.002

KUSTURICA, M. P., SABO, A., TOMIC, Z., HORVAT, O. \& S־OLAK, Z. (2012) Storage and disposal of unused medications: Knowledge, behavior, and attitudes among Serbian people, International Journal of Clinical Pharmacy, 34(4): 604-610. https://doi.org/10.1007/ s11096-012-9652-0

KUSTURICA, M. P., TOMAS, A. \& SABO, A. (2016) Disposal of unused drugs: Knowledge and behavior among people around the world, IN: P. DE VOOGT (Ed.). Reviews of environmental contamination and toxicology, pp. 71-104 (Springer, Cham).

MASSOUD, M. A., CHAMI, G., AL-HINDI, M. \& ALAMEDDINE, I. (2016) Assessment of household disposal of pharmaceuticals in Lebanon: Management options to protect water quality and public health, Environmental Management, 57(5): 1125-1137. https://doi.org/ 10.1007/s00267-016-0666-6

MASONER, J. R., KOLPIN, D. W., FURLONG, E. T., COZZARELLI, I. M., GRAY, J. L. \& SCHWAB, E. A. (2014) Contaminants of emerging concern in fresh leachate from landfills in the conterminous United States, Environmental Science: Processes and Impacts, 16(10): 2335-2354. https://doi.org/10.1039/C4EM00124A

MINISTRY OF HEALTH MALAYSIA (2013) Return your medicines program, https://www. pharmacy.gov.my/v2/en/content/return-your-medicines-program.html (1 January 2020).

NAKADA, N., TANISHIMA, T., SHINOHARA, H., KIRI, K. \& TAKADA, H. (2006) Pharmaceutical chemicals and endocrine disrupters in municipal wastewater in Tokyo and their removal during activated sludge treatment, Water Research, 40(17): 3297-3303. https://doi.org/10.1016/j.watres.2006.06.039

PATWARY, M. A., O'HARE, W. T., STREET, G., MAUDOOD ELAHI, K., HOSSAIN, S. S. \& SARKER, M. H. (2009) Quantitative assessment of medical waste generation in the capital city of Bangladesh, Waste Management, 29(8): 2392-2397. https://doi.org/10.1016/j. wasman.2009.03.021 
PERSSON, M., SABELSTRÖM, E. \& GUNNARSSON, B. (2009) Handling of unused prescription drugs - Knowledge, behaviour and attitude among Swedish people, Environment International, 35(5): 771-774. https://doi.org/10.1016/j.envint.2008.10.002

SHEALY, K., O'DAY, P. \& EAGERTON, D. (2014) The needs and opportunities for medication disposal programmes, Journal of Pharmacy Technology, 30(5): 147-150. https://doi.org/10.1177\%2F8755122514545519

SU LAN, Y., SZE LING, T., QING LIANG, G. \& SIOW YEN, L. (2018) Utilization of Ministry of Health medication return programme, knowledge and disposal practice of unused medication in Malaysia. Journal of Pharmacy Practice and Community Medicine, 4(1): 7-11. http://dx.doi.org/10.5530/jppcm.2018.1.3

TONG, A. Y., PEAKE, B. M. \& BRAUND, R. (2011) Disposal practices for unused medications around the world, Environment International, 37(1): 292-298. https://doi.org/ 10.1016/j.envint.2010.10.002

WORLD HEALTH ORGANIZATION (WHO). (2002) Promoting rational use of medicines, https://www.who.int/activities/promoting-rational-use-of-medicines (1 January 2020).

WU, M., ATCHLEY, D., GREER, L., JANSSEN, S., ROSENBERG, D. \& SASS, J. (2009) Dosed without prescription: Preventing pharmaceutical contamination of our nation's drinking water — white paper, https://www.nrdc.org/resources/dosed-without-prescriptionpreventing-pharmaceutical-contamination-our-nations-drinking (1 January 2020). 